\title{
PELATIHAN KADER PENGENDALIAN PENYAKIT HIPERTENSI PADA MASYARAKAT DI DESA PANGKALAN TIGA \\ ${ }^{1}$ Lieni Lestari \\ ${ }^{1}$ STIKes Borneo Cendekia Medika Pangkalan Bun \\ ${ }^{1}$ Email : lienilestari@gmail.com
}

\begin{abstract}
ABSTRAK
Pendahuluan: Penyakit hipertensi di Indonesia pada tahun 2010 menduduki urutan ke tujuh dari 10 besar penyakit terbanyak rawat inap se-Indonesia. Adapun prosentase sepuluh penyakit terbesar tersebut sebagai berikut : diare dan gastritis $(21,5 \%)$, demam berdarah dengue $(17,7 \%)$, demam tifoid dan paratifoid $(12,3 \%)$, penyakit kehamilan dan persalinan $(12,2 \%)$, dispepsia $(7,4 \%)$, cedera $(6,5 \%)$, hipertensi esensial $(5,9 \%)$, cidera intrakranial $(5,8 \%)$, infeksi saluran nafas bagian atas $(5,4 \%)$, pneumonia $(5,1 \%)$. Penyakit darah tinggi atau hipertensi adalah suatu keadaan dimana seseorang mengalami peningkatan tekanan darah diatas normal yang di tujukan oleh angka sistolic (bagian atas) dan diastole (angka bawah) pada pemeriksaan tensi darah menggunakan alat ukur tekanan darah baik yang berupa cuff air raksa ataupun alat digital. Metode: Jenis pengabdian masyarakat yang dilakukan adalah pelatihan kader pengendalian hipertensi pada masyarakat di wilayah kerja Puskesmas Pangkalan Tiga. Pengabdian masyarakat dilakukan pada hari Jumat, 9 Juni 2017 jam 08.00 WIB. Pada kegiatan pengabdian ini menggunakan metode ceramah untuk pemaparan materi dan demonstrasi untuk mempraktekkan pengukuran tekanan darah. Tujuan: Kader (peserta) dapat memahami tentang hipertensi dan cara mengukur tekanan darah. Perlunya pelatihan kader untuk pengendalian penyakit penyakit Diabetes mellitus, DHF dan lainnnya.
\end{abstract}

\section{Kata kunci : Kader, Hipertensi, Masyarakat \\ TRAINING OF HYPERTENSION DISEASE CONTROL LEADERS IN COMMUNITIES IN THREE PANGKALAN VILLAGES}

\begin{abstract}
Introduction: Disease hypertension in indonesia in 2010 ranked second with seven out of 10 large se-indonesia disease in patients. As for prosentase ten largest disease is as follows: diarrhea and gastritis (21,5\%), dengue fever (17,7\%), typhoid fever and paratifoid (12,3 $\%$ ), disease pregnancy and childbirth (12,2\% ), dyspepsia ( 7,4\% ), 6,5\%) (injury, 5,9 $\%$ ) (essential hypertension, injured intrakranial ( 5,8 \%), infection of the upper breath ( $5,4 \%)$, pneumonia ( 5,1 \% ). High blood disease or hypertension is a situation where a person subjected to a rise in blood pressure above normal in stretch by numbers sistolic ( ) ( and the diastole of the upper part of the lower) tension to the examination of a blood used a blood pressure monitor of cuff mercury or digital instrument. Method: A method of: a kind of devotion the community can be done is by the cadre training on the control of hypertension directed to the community in the work area of public health clinics have been a haven and a landing three.Devotion the community start on friday, 9 june 2017 hours 08.00 wib western indonesia time .Of companies involved in marketing devotion is provided by way of a method of lectures to an examination of course material and of demonstration as to practice the measurement of the pressure of the blood .The purpose of: ( cadres participants ) to fully understand the about hypertension and the means of measuring blood pressure.To the need for the training cadres to control of disease of diabetes mellitus, dhf and the other.
\end{abstract}


Key words: caders, hypertension, the community

\section{Pendahuluan}

Menurut American

Heart

Association (AHA) angka kejadian hipertensi di Amerika tahun 2011 pada populasi umur diatas 18 tahun di temukan $27 \%$ mengalami hipertensi baik pria maupun wanita dan angka kejadian akan bertambah dengan umur. Angka kejadian hipertensi lebih banyak terjadi pada African Americans, khususnya wanita, kemudian pada kulit hitam lebih tinggi dibandingkan kulit putih (AHA, 2011).

Penyakit hipertensi di Indonesia pada tahun 2010 menduduki urutan ke tujuh dari 10 besar penyakit terbanyak rawat inap se-Indonesia. Adapun prosentase sepuluh penyakit terbesar tersebut sebagai berikut : diare dan gastritis $(21,5 \%)$, demam berdarah dengue $(17,7 \%)$, demam tifoid dan paratifoid $(12,3 \%)$, penyakit kehamilan dan persalinan $(12,2 \%)$, dispepsia $(7,4 \%)$, cedera $(6,5 \%)$, hipertensi esensial $(5,9 \%)$, cidera intrakranial $(5,8 \%)$, infeksi saluran nafas bagian atas $(5,4 \%)$, pneumonia $(5,1 \%)$ (Depkes RI 2011).

Sepuluh besar penyakit di provinsi Lampung pada tahun 2011 adalah Influenza $(45,4 \%)$, diare $(23,95 \%)$, hipertensi $(15,89 \%)$, tifus perut kronis $(4,83 \%)$, malaria klinis $(2,52 \%)$, tersangka TB paru $(2,44 \%)$, diare berdarah $(2,17 \%)$, diabetes mellitus (1,19\%), TBC paru BTA positif $(0,79 \%)$, pneumonia $(0,78 \%)$. Dari data diatas hipertensi menduduki urutan ketiga, dengan jumlah 81.006 orang $(15,9 \%)$ (Dinas Kesehatan Propinsi Lampung, 2011).

Menurut Survey terpadu

Penyakit (STP) 10 penyakit besar di
Puskesmas Kota Metro pada bulan Januari sampai dengan bulan Desember hipertensi menduduki peringkat keempat dengan jumlah 10632 orang $(8,23 \%)$. Adapun data sepuluh penyakit terbanyak di puskesmas se-kota metro tahun 2011 sebagai berikut : Infeksi akut lainnya $(41,1 \%)$, gastritis $(14,5 \%)$, penyakit pada sistem otot dan jaringan pengikat $(12,5 \%)$, penyakit tekanan darah tinggi $(8,23 \%)$, penyakit lainnya pada pernafasan bagian atas $(6,4 \%)$, penyakit kulit alergi $(6,34 \%)$, diare $(3,09 \%)$, penyakit mata lainnya (2,79\%), gangguan gigi dan jaringan penyangga lainnya $(2,68 \%)$, penyakit pulpa dan jaringan periapikal $(2,38 \%)$. Frekuensi penyakit hipertensi yang tertinggi se-Kota Metro terdapat pada masyarakat di wilayah kerja puskesmas Metro kota yaitu 3.193 orang pada tahun 2011 (Dinas Kesehatan Kota Mero, 2011).

Penyakit darah tinggi atau hipertensi adalah suatu keadaan dimana seseorang mengalami peningkatan tekanan darah diatas normal yang di tujukan oleh angka sistolic (bagian atas) dan diastole (angka bawah) pada pemeriksaan tensi darah menggunakan alat ukur tekanan darah baik yang berupa cuff air raksa ataupun alat digital (Smeltzer, 2002).

$$
\text { Menurut William (2007) }
$$

terdapat dua faktor resiko pada penyakit hipertensi yaitu faktor yang tidak dapat diubah atau dikontrol dan faktor yang dapat diubah atau dikendalikan. Faktor yang tidak dapat diubah adalah riwayat keluarga dengan hipertensi, umur, ras dan etnik dan penyakit diabes mellitus. Sedangkan 
faktor yang dapat diubah atau dikendalaikan adalah obesitas, mengkonsumsi garam, olah raga, mengkonsumsi alkohol dan merokok.

Berdasarkan penelitian yang saya lakukan dengan judul penelitian faktorfaktor yang berhubungan dengan komitmen pencegahan tersier penyakit hipertensi pada masyarakat di wilayah kerja puskesmas menujukkan: tidak ada hubungan persepsi manfaat dengan komitmen, ada hubungan persepsi rintangan dengan komitmen, ada hubungan persepsi kemampuan diri dengan komitmen, ada hubungan sikap dengan komitmen. Faktor yang paling dominan berhubungan dengan komitmen pencegahan tersier penyakit hipertensi adalah persepsi rintangan.

\section{Metode}

Jenis pengabdian masyarakat yang dilakukan adalah pelatihan kader pengendalian hipertensi pada masyarakat di wilayah kerja Puskesmas Pangkalan Tiga. Pengabdian masyarakat dilakukan pada hari Jumat, 9 Januari 2020 jam 08.00 WIB. Metode dalam kegiatan pengabdian ini menggunakan metode ceramah untuk pemaparan materi dan demonstrasi untuk mempraktekkan pengukuran tekanan darah.

\section{Hasil}

Dari hasil pelatihan kader yang diselenggarakan pada 9 Januari 2020 didapatkan hasil sebagai berikut:

1. Pelatihan kader pengendalian hipertensi dibuka dan dan dihadiri oleh kepala puskesmas pangkalan tiga.

2. Pelatihan dilaksanakan pada bulan Januari 2020 , waktu pelaksanaan dari jam 08.00 s.d 12.00 WIB.
3. Pelatihan sesi pertama pada pukul 08.00 s/d 10.00 dengan materi tentang hipertensi dan cara pengukuran tekanan darah kemudian dilanjutkan sesi kedua pada pukul 10.15 WIB dengan materi praktik pengukuran tekanan darah.

4. Sesi pertama tentang materi hipertensi peserta $90 \%$ dapat memahami materi yang diberikan.

5. Sesi kedua tentang materi praktek pegukuran tekanan darah peserta 90\% dapat mempraktikkan cara pengukuran tekanan darah dengan benar.

\section{Pembahasan}

\section{Komitmen peserta}

Dari evaluasi yang dilakukan pada peserta kurang lebih $90 \%$ dapat memahami materi tentang hipertensi dan cara pengukuran tekanan darah. Kondisi pelaksanaan pengabdian tentang pengendalian hipertensi juga dapat ditunjukkan dengan komitmen peserta dalam mengikuti pelatihan pengendalian hipertensi. Hal ini ditunjukkan dengan komitmen peserta mengikuti pelatihan secara penuh waktu dari awal sampe akhir pelatihan.

Definisi komitmen

menurut kamus besar bahasa indonesia adalah perjanjian untuk melakukan sesuatu (kontrak) dan mempunyai nilai rasa positif. Komitmen dalam mengikuti pelatihan penyakit hipertensi dapat ditunjukkan dari hasil pengabdian. Hasil evaluasi menunj ukkan bahwa peserta yang berkomitmen (100\%) dalam 
mengikuti pelatihan pengendalian hipertensi pada masyarakat diwilayah kerja puskesmas pangkalan tiga.

Berdasarkan uraian diatas maka dapat disimpulkan bahwa peserta berkomitmen terhadap pengendalian hipertensi pada masyarakat di wilayah pangkalan tiga. Kondisi ini menurut penulis dikarenakan masyarakat merasa perlu dan mau melakukan program pengendalian penyakit hipertensi.

2. Persepsi Manfaat bagi peserta

Menurut Pender (2002) persepsi manfaat adalah manfaat tindakan secara langsung memotivasi perilaku dan tidak langsung mendetermin rencana kegiatan untuk mencapai manfaat sebagai hasil. Manfaat tadi menjadi gambaran mental positif atau reinforcement positif bagi perilaku. Hasil evaluasi menunjuk kan bahwa peserta pelatihan yang berpersepsi ada manfaat (90\%) dibandingkan dengan yang berpersepsi tidak ada manfaat.

Berdasarkan uraian diatas maka dapat disimpulkan bahwa peserta pelatihan kader diwilayah puskesmas mempunyai persepsi ada manfaat terhadap pengendalian penyakit hipertensi. Kondisi ini menurut penulis ditunjukkan dari masyarakat yang sudah tau, mau dan mampu melaksanakan mengendalikan penyakit hipertensi.

\section{Persepsi Kemampuan Diri}

Menurut Bandura dalam Pender (2002) kemampuan diri adalah kemampuan seseorang untuk mengorganisasi dan melaksanakan tindakan utama menyangkut bukan hanya skill yang dimiliki seseorang tetapi keputusan yang diambil seseorang dari skill yang dia miliki. Keputusan efficacy seseorang diketahui dari hasil yang diharapkan yaitu kemampuan seseorang menyelesaikan suatu pekerjaan tertentu di mana hasil yang diharapkan adalah suatu keputusan dengan konsekuensi keuntungan.

Hasil evaluasi menunjukka $\mathrm{n}$ bahwa peserta yang berpersepsi kemampuan diri tinggi (80\%) dibandingkan dengan yang berpersepsi tidak berkemampuan diri. Berdasarkan uraian diatas maka dapat disimpulkan bahwa kader kesehatan diwilayah kerja puskesmas mempunyai persepsi Tinggi tentang kemampuan dirinya terhadap pengendalian penyakit hipertensi. Kondisi ini menurut penulis dikarenakan masyarakat sudah tau, mau dan mampu mengendalikan penyakit hipertensi.

\section{Sikap}

Sikap menurut Pender (2002) adalah respons emosional dan status fisiologis selama perilaku sebagai sumber dari informasi efficacy. Sikap pengaruh aktifitas diajukan sebagai mempengaruhi perilaku kesehatan secara langsung atau tidak langsung melalui efficacy diri dan komitmen pada rencana kegiatan.

Hasil evaluasi menunjukkan

bahwa peserta pelatihan yang bersikap positif (95\%) dibandingkan dengan yang bersikap negatif. Terbukti bahwa 
peserta pelatihan yang bersikap positif dalam pengendalian hipertensi lebih tinggi. Berdasarkan uraian diatas maka dapat disimpulkan bahwa mempunyai sikap positif terhadap pengendalian penyakit hipertensi. Kondisi ini menurut penulis dikarenakan masyarakat sudah tau, mau dan mampu melaksanakan program pengendalian penyakit hipertensi.

\section{Kesimpulan dan Saran}

\section{Kesimpulan}

Pelatihan kader pengendalian hipertensi dapat disimpulkan :

1. Kader (peserta) dapat memahami tentang hipertensi dan cara mengukur tekanan darah.

2. Sebagian besar kader (peserta) berkomitmen dalam pengendalian hipertensi .

3. Sebagian besar kader (peserta) merasakan manfaat dalam pengendalian hipertensi .

4. Sebagian besar kader (peserta) mempunyai kemampuan diri dalam pengendalian hipertensi .

5. Sebagian besar kader (peserta) mempunyai sikap yang positif dalam pengendalian hipertensi.

\section{Saran}

1. Bagi peserta pelatihan kader perlunya aplikasi pengendalian hipertensi pada masyarkat disekitar lingkungannya.

2. Perlunya pelatihan kader untuk pengendalian penyakit penyakit Diabetes mellitus, DHF dan lainnnya.
Daftar Pustaka

Depkes RI, Data Kejadian Penyakit Pada Tahun 2011.

Dinas Kesehatan Kota Metro, Sepuluh Besar Penyakit Pada Tahun 2011.

Dinas Kesehatan Provinsi Lampung, Data Penyakit Pada Tahun 2011.

Davidson, Depression Symtoms predict Early Hypertension Incidence In Young Adults, 2000.

Dongol, Hubungan obesitas dan asupan garam terhadap kejadian hipertensi pada lakilaki 40 tahun keatas studi di puskesmas padangsari banyumanik Semarang, Skipsi, UNES, 2008

Elisabeth, Faktor-faktor yang berhubungan dengan hipertensi pada lansia di posyandu lansia wilayah kerja puskesmas parsoburan kecamatan sianta marihat pematangsiantar,Skripsi 2011 Udjianti,W (2010). Keperawatan

Kardivaskular.Salemba Medika Jakarta

Wolff,. Hipertensi; Cara mendeteksi dan Mencegah Tekanan Darah Tinggi Sejak Dini (Terjemahan), PT. Bhuana Ilmu Populer Kelompok Gramedia, Jakarta, 2008 